\title{
Rural Banking in Ghana and Its Impact on Rural Farmers. Case Study of the Birim South District, Ghana
}

\author{
Cleland F. Afful ${ }^{1}$, Jiri Hejkrlík ${ }^{1} \&$ Tomas Doucha ${ }^{1}$ \\ ${ }^{1}$ Department of Economics and Development, Faculty of Tropical AgriSciences, Czech University of Life \\ Sciences, Prague, Czech Republic \\ Correspondence: Cleland Fiifi Afful, Czech University of Life Science. Department of Economics and \\ Development, Faculty of Tropical AgriSciences Kamycka 129, 16521 Prague 6-Suchdol, Czech Republic. Tel: \\ 420-773-599-156. E-mail: cfafful@yahoo.com
}

\author{
Received: July 24, 2015 Accepted: October 5, 2015 Online Published: October 26, 2015 \\ doi:10.5539/ass.v11n25p101 URL: http://dx.doi.org/10.5539/ass.v11n25p101
}

\begin{abstract}
This study examines the impact of financial institutions, especially rural banks on rural farmers. It analyses the role rural banks play in agricultural development and food security of the Birim South District in the Eastern Region of Ghana.

The aim of the research was to (1) evaluate the rationale of the introduction of rural banks in Ghana and their impact on the rural folks (especially farmers) (2) establish a link between rural banking and food security (3) understand constraints farmers face in their dealings with the bank. And to analyze the various ways the rural bank impact on the lives of the farmers.

Questionnaires and interviews were used to elicit responses from 220 clients (mostly farmers) of the South Birim Rural Bank Ltd.

The paper demonstrates that the rural bank has a positive impact on the people in terms of giving them something to fall on when times are hard translating into poverty alleviation and food security as well as financial advisory services.
\end{abstract}

Keywords: financial advisory, food security, Ghana, poverty alleviation, Rural Bank

\section{Introduction}

Poverty, malnutrition and hunger have over the last half a century brought Africa to the world's attention, especially in the 1980's and early 1990's. Drought, low food production, poor infrastructure and increase in population are a few contributing factors to this phenomenon.

It should be of note that agriculture does not only improve hunger and decrease poverty through food production and its aftermath of food availability, stability of food supply and lowering of food prices, but it also has a rippling effect on employment and income generation which covers the issue of accessibility of food.

Food security has been known to have so many definitions for research and policy analysis. The breakdown of these definitions can be accounted for in 4 spheres: availability, accessibility, utilization and stability of food. Thus, for food security to be ensured there must be availability and stability of food, which can be achieved through agricultural development. Accessibility in the form that rural folks will have the means to acquire the food. And finally, use the food in the right context.

Many researchers stress the importance of credit in increasing agricultural productivity, income of farmers and subsequently food security (see for example Bortey, 1997; Kimathi, 2008; Egyir, 2010; Mann et al., 2010). To these researchers, inaccessibility of credit is the bane of development of small scale agriculture. A further thematic trend in this discourse is the opinion that improved technologies in agriculture can be associated with increased demand for working capital or fixed capital (e.g. pesticides and tractor respectively) or both and for this reason, availability of finance is most important to the total factor productivity in agriculture (Desai, 1989; Seini, 2002). When well-functioning financial institutions are absent, growth opportunities are missed and poverty and inequality continue to persist (World Bank, 2007). Owusu-Acheapong (1986, p. 54) is of the view that the most important factor in rural farming in Ghana is the availability of credit and not land as compared to 
other countries. To him access to credit can turn the less productive and traditional simple tools into sophisticated capital equipment for enhancing production and therefore increase food availability.

In most of the developing world, incomes of most farmers are low, static and dependent on the whims and caprices of the weather. Income from agriculture vary year to year and season to season and a household's inability to control such fluctuation in consumption either by access to savings or credit leaves them vulnerable to food insecurity of transitory nature and in the long run chronic food insecurity. Effective credit facilities thus become important to farmers, as it creates an insured blanket for future shocks and in the long run reduce the need to liquidate their productive asset (FAO, 1994; Habibullah, 1982; Bauer, 1952) and giving them the opportunity to acquire the basic needs of man.

FAO (1994) categorises the sources of rural credit under institutional and non-institutional sources. Non institutional sources such as credits provided by relatives, traders, friends, money lenders, cooperatives, commission agents are well documented sources (Ardener, 1964; Adjetey, 1978; Aryeetey \& Gockel, 1991). Friends and relatives source of loans usually attract no interest or collateral but the ones provided by money lenders and traders attract exorbitant interest rates (Aryeertey, 1994). To some researchers (Lele, 1989; Mellor, 1976), financial strength of these non-institutional lenders are too weak to sustain the long term finance necessary for investment in assets such as tractors, market infrastructure, irrigation and other agricultural implements. Other researchers are of the opinion that small scale farming systems dependency on capital transfer means that savings mobilization which is very important cannot be sustain by informal lenders as they do not have the deposit facilities for this purpose (Desai, 1989; Von Pischke et al., 1983). This goes a long way to suggest agricultural growths dependent on effective and stable financial markets like institutional source of credit, thus making a case for institutionalize source of credit.

Burgess and Pande (2005) revealed in their studies of rural India that the establishment of banks in rural areas led to structural change and poverty reduction. It is based on the fact that the concept of the 'rural bank', a banking entity which is co-operative in character but provides a much wider range of services, evolved.

Other researchers are on the opposing side when it comes to rural and microfinance institutions like rural banks and how they help the rural population in areas such as poverty alleviation. Hulme and Mosley (1996) for example assert that rural banks are not the solution when it comes to rural poverty alleviation, since in some cases they tend to make poor people worse off. But this view is refuted by Asiama and Osei, 2007.who asserts that the provision of material capital to the poor does not only strengthened their sense of dignity but it can help to empower them to participate in the economy and society.

In Ghana, before the advent of rural banks, it suffices to say that even in areas where institutional source of credit existed rural dwellers had to travel long distances to receive payments (such as salary and pension deposits), transfer funds, and cash check payments for their agricultural produce (Ajai \& Azeb, 2010). Because of this financial limitation and its effect on rural economics and rural development in general, the Government of Ghana introduced policies to remedy this and improve agriculture. One of such policy measure was a condition for commercial banks to lend at least $20 \%$ of their portfolio for the agricultural sector in rural areas (Addeah, 1989). Subsequent this led to the establishment of specialized banks, namely, the Agricultural Development Banks (ADB) and the National Investment Banks (NIB) in 1965 and 1963 respectively to help boost agriculture (Bortey, 1997; Egyir, 2010). These banks opened branches in rural areas with emphasis on cocoa growing areas (Addeah, 2001).

However, it is interesting to note also that these specialized banks in the end used their rural branches mainly to make payments to cocoa farmers and collect deposits for lending in urban areas (Gyamfi, 1987). Further, these special banks had limited coverage in rural areas with $27 \%$ of branches located in rural areas and only lending to $15 \%$ small scale farmers (Mensah, 1993; Renade, 1994).

The idea of rural bank evolved in Ghana in 1976 when the government of Ghana, through the Bank of Ghana (BOG) established rural banks with the aim of channeling credit to productive rural ventures and to promote rural development; a strategy to bring the economic and social life of the rural poor to an acceptable standard (World Bank 1975). According to the Association of Rural Banks (1992), "The aims of Rural Banks are:

- To stimulate banking habits among rural dwellers;

- To mobilize resources locked up in the rural areas into the banking systems to facilitate development; and

- To identify viable industries in their respective catchments [areas] for investment and development."

In pursuing the above objectives, the BOG identify agriculture as a critical factor (since agriculture in Ghana is the major employer of the rural folks) and has mandated that agricultural loans should represent at least $50 \%$ of 
any RB's loan portfolio at any point in time, with approximately $30 \%$ for cottage industries ${ }^{1}$ and a maximum of $20 \%$ for trade and transport (see Figure 1).

\section{Credit Allocation}

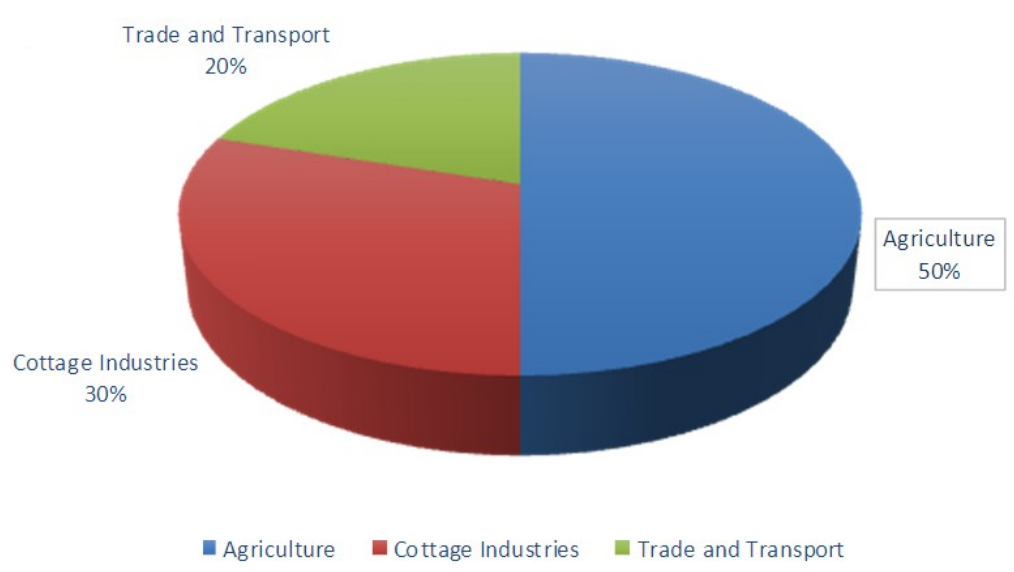

Figure 1. Mandatory sectorial allocation of rural bank loans portfolio

Source: The Bank of Ghana's (2004).

However a critical assessment of this directive by researcher Essel and Newsome (2000) showed in their studies that credit for direct production in agriculture constituted only about $15 \%$ of the total loan portfolio of their case study bank instead of the $50 \%$ stipulated by the BOG, this view is backed by Nissanke and Aryeetey (1998) research that, as at 1993 , RB's credit extended to the agricultural sector stood at $27 \%$. This is a big, criticism to the effectiveness of rural banks in terms of agricultural development and subsequently food security.

Rural banks are mainly unit's banks with ownership structure being members of the rural community through the purchase of shares. In recent times, rural banks in Ghana are the largest providers of formal financial services in rural areas and hold a big chunk of the total banking outlets in the country (IFAD, 2008). As of January 2013, there were 137 registered rural banks in Ghana according to the Bank of Ghana.

This paper therefore makes an empirical contribution to the existing literature by examining whether rural banking translates into increased credit and savings opportunities for poverty reduction and rural agricultural development and thereby improving the food security of the rural folks.

\section{Methodology}

This study adopted a case study approach based on farmer's views to examine the impact of rural banks in promoting rural agricultural development to reduce poverty and increasing food security. To measure the extent of rural banks impact on the rural farmers, customer database of South Birim Rural Bank Ltd in the Eastern Region of Ghana was used.

Collection of data was done in June to August of 2013. Structured questionnaires were employed with information on demographics, occupation, education, savings and loans accessibility and any other rural bank activities. Both open and close ended questionnaires were used. With majority of the questions (23 in number) being the later. As a qualitative support, non-structured interviews were used to include management, staffs as well as the clients of the bank opinions. The qualitative data focused on the operational activities of the banks and how it has improved (or otherwise) the income of the rural people. Using descriptive statistics to analyze findings, a convenient sampling procedure was used to select a total of 220 of the banks client who were mainly farmers for examination (but with special emphasis on having a balance in terms of gender) for the study. Almost all the 220 were farmers but they had other secondary occupation. This sample size was determined based on the banks record of having 512 clients whose primary occupation is farming. A confidence level and interval of $95 \%$ and $5 \%$ respectively were used to arrive at the 220 respondents.

The respondents were asked about what assistance they get from the banks, how easily they are able to acquire 
loans to improve their work, how promptly the loan is and what constraint they face in their day to day dealings with the bank. They were also asked if they have any opinion on what the rural banks could do improve their work and also about how important these rural banks have on themselves and their community as a whole. The unstructured section of the questionnaire and follow up unstructured interviews were used identify positive and negative perception of rural banking as seen by the farmers. These were done to strengthen the data collected via questionnaire and also to make up for any comments that were neglected in terms of the structured questionnaire. To ascertain whether interest rates from the bank has any bearing on the number of farmers who demand for loan to improve their work. A linear regression analysis was draw from the information gathered.

A number of indicators were used to assess the extent by which the rural bank has affected the lives of its client. The main indicators were ranked using a five point Likert Scale. The indicators include changes in income, output, savings level and employment generation. The values assigned to the response had 1 representing "weak agreement" rising up to 5 representing "strong agreement". To measure the extent of effect, the researcher employs a modify version of Eta Square, which is given by the formula

$$
\text { EtaSquare }=\frac{t^{2}}{t^{2}+N-1}
$$

Where:

$\mathrm{t}=\mathrm{t}$-value; $\mathrm{N}-1=$ degree of freedom.

And based on the interpretation of Cohen, (1988) guidelines which states that: $0.01=$ small effect, $0.06=$ moderate effect, 0.14 = large effect

All information got from respondents are analyzed in the frequently applied software package Statistical Package for the Social Sciences (SPSS) whiles Microsoft excel was also used for data output management and graphing. In order to achieve the stated objective of the study it is hypothesized as follows: Rural Banking promotes rural agricultural development and therefore ensures food security.

\section{Results and Discussion}

Table 1. Demographic characteristics of respondents

\begin{tabular}{llll}
\hline Variables & & Frequency & Percentage (\%) \\
\hline \multirow{2}{*}{ Sex } & Male & 110 & 50 \\
& Female & 110 & 50 \\
Age & $20-29$ & 66 & 30 \\
& $30-39$ & 53 & 24.1 \\
& 40 and Over & 101 & 45.9 \\
Occupation & Farming (only) & 111 & 50.5 \\
& Carpentry & 12 & 5.5 \\
& Commercial Drivers & 14 & 6.4 \\
& Mechanic & 8 & 3.6 \\
Education & Elementary & 78 & 35.5 \\
& Sec/Voc/Com & 81 & 36.8 \\
& Tertiary & 20 & 9.1 \\
& No Education & 41 & 18.6 \\
\hline
\end{tabular}

The socioeconomic profiles of the respondents as presented in Table 1 shows half of the respondent from each of the sexes. This was done in order to get a fair or a balance response from the male and female farmers. In terms of age, $54.1 \%$ of the respondents are in age group below 40 years whiles $45.9 \%$ are in the age group above 40 years. Table 1 also illustrates that the respondents are in various secondary occupation (even though farming was primary occupation) such as trading, carpentry, driving and mechanics with those whose primary occupation was farming making up $50.5 \%$ of respondents. Education level of the respondents yielded $9.1 \%$ for tertiary education while $18.6 \%$ have no education. $36.8 \%$ secondary education and $35.5 \%$ have elementary education.

The study revealed based on the banks record, their savings products, is categorized as regular savings accounts, 
current accounts, susu ${ }^{2}$ deposits, and fixed or time deposits. The small nature and shortness of these accounts encourage the inhabitants of the area to easily access the banks services. Opening an account at the bank requires a minimum balance of GHC5 (equivalent of 2.22 USD) according to the banks records. Table 2 shows the savings pattern of the study area. While $36.8 \%$ of the respondents have the regular saving accounts, $29.1 \%$ susu account, $30.5 \%$ current accounts and only $3.6 \%$ have fixed deposits. The reason for the high savings account was explained as emergency funds and also for the interest the respondents believe it generate. This dispels assertions by Bouman (1989) and Porter (1964) that poor and low-income people do not embark on savings (that is if one has to look at it from the premises that most of the poor live in rural areas). Current accounts holders on the other hand said they made that choice in order to have a faster business transaction. The importance of these deposits services cannot be ignored. According to Oloyede (2008) savings help households build up asset which can be used as collateral when the need be as well as capital to cater for future needs of the household. All (100\%) of the respondents do save some of their gains from their occupation in the financial institutions since they believe it's the safest place for keeping their monies. This may however also be because of the financial assistance provided by the rural bank (in the area of loans) according to the management of the bank. $77.3 \%$ of the respondent claimed they have once or more repeatedly applied for loans with the remaining $22.7 \%$ citing mentioning the high interest rate and collateral as serious impediment to them applying for loan and they prefer to only save their money at the bank.

Standard loan approval time ranged from a week to $11+$ weeks according to respondents. Group borrowing was also allowed but with special prerequisite like borrowers should not exceed 20 people and they should attend several training session on loan management. Loan repayment conditions are determined based on the borrower's ability to pay. Half of the respondents had enjoyed credit from the bank for less than 5years, with $36.5 \%$ between $6-8 y e a r s$ and $13.5 \%$ more than 9years. This gives the idea that only few farmers has enjoyed credit from the bank for a longer time.

It is interesting to note about $90 \%$ of the loan recipients used the facility for agricultural purpose as represented in Figure 2. This goes to suggest that if giving financial backing, most farmers will use it to increase productivity on their farm.

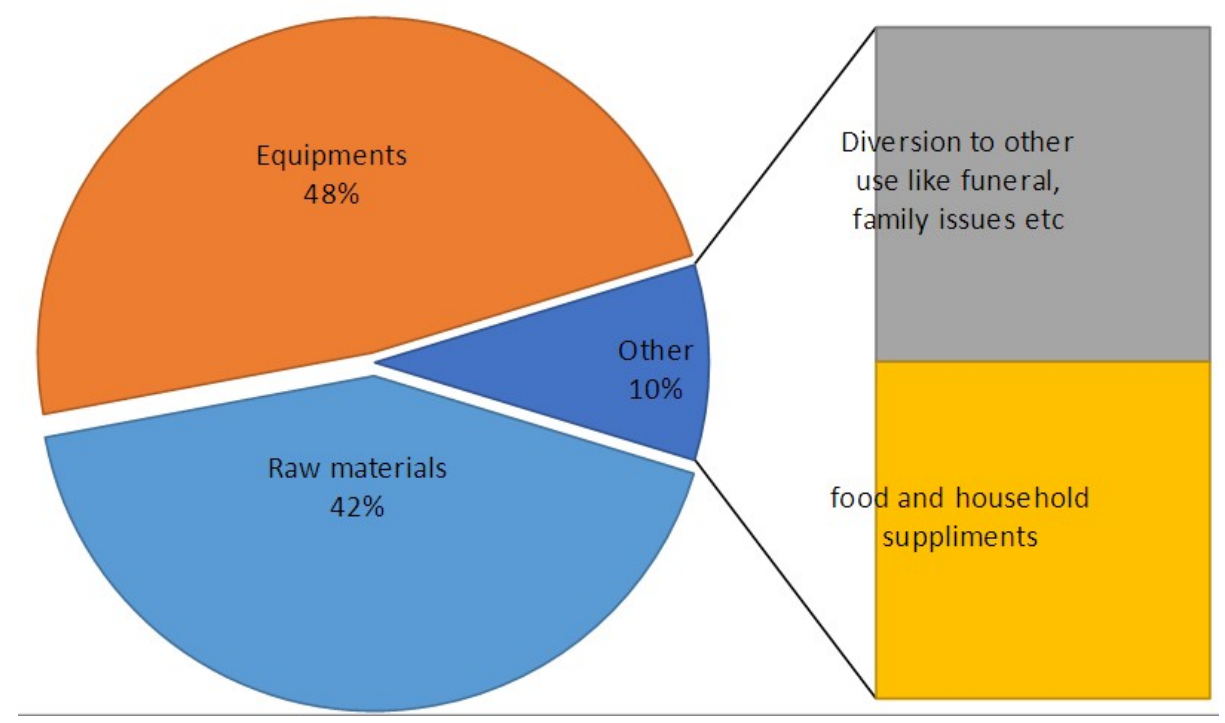

Figure 2. Credit use of respondent

Management of the bank confirmed the highest accounts opened by clients are savings accounts. Management further explained that all account holders were entitled to apply for loan and that they asked for collaterals in most cases in order to protect the interest of the bank and also ensure that clients are committed to payment of their loans. Interest charges on loans ranged from $25 \%$ in the year 2000 until 2010 when it changed to $28 \%$ and finally dropped to $27 \%$ in 2012 . 
Table 2. Interest rates and demand for loan

\begin{tabular}{ccc}
\hline Year & Loan Demand & Interest Rate (\%) \\
\hline $\mathbf{2 0 0 0}$ & 140 & 25 \\
$\mathbf{2 0 0 1}$ & 152 & 25 \\
$\mathbf{2 0 0 2}$ & 161 & 25 \\
$\mathbf{2 0 0 3}$ & 153 & 25 \\
$\mathbf{2 0 0 4}$ & 163 & 25 \\
$\mathbf{2 0 0 5}$ & 176 & 25 \\
$\mathbf{2 0 0 6}$ & 201 & 25 \\
$\mathbf{2 0 0 7}$ & 168 & 25 \\
$\mathbf{2 0 0 8}$ & 172 & 25 \\
$\mathbf{2 0 0 9}$ & 187 & 28 \\
$\mathbf{2 0 1 0}$ & 206 & 28 \\
$\mathbf{2 0 1 1}$ & 176 & 28 \\
$\mathbf{2 0 1 2}$ & 185 & 27 \\
\hline
\end{tabular}

The demand for loan fluctuates without regards for the interest rate. Even in the year 2006 when there was increase in the interest rate, demand astonishingly increased as well. A linear equation in SPSS to find the relations between the demand for loan and the interest rate came with the equation $\mathrm{Y}=8.372 \mathrm{X}-44.085$. Where $\mathrm{Y}$ is number of people who demanded for loan and $\mathrm{X}$ is the bank charges or interest rate. An analysis of this is that when the interest rate is zero percent $(X=0)$, the demand for loan decreases by 44 farmers. Furthermore when there is an increase in the interest rate, the demand for loan increase by just 8 . A co-efficient of determination calculated to determine how much does interest rate influence demand for loan. The calculated co-efficient of determination was equal to 0.344 . This implies that approximately 34 per cent of the factor influences demand for loan.

The average credit cycle - that is, the number of times a particular borrower secured a credit - shows an interesting phenomena (see Table 3).

Table 3. Summary of loan cycle

\begin{tabular}{ll}
\hline Mean & $\mathbf{4 2 . 5}$ \\
Median & 39.5 \\
Maximum & 67 \\
Minimum & 12 \\
Standard Deviation & 25.25206 \\
No of farmers & 170 \\
\hline
\end{tabular}

The difference between the mean and the median coupled with the standard deviation about the mean indicates that farmers get access to loans from the Rural Bank quite often. This might also dispel the initial fears that the high level of interest on loan scares farmers from accessing them.

Employing the Eta squared formula based on interpretation of Cohen (1988) the effect size of the impact of rural bank on income is calculated as

$$
\text { EffectSize }=\frac{32.193^{2}}{32.193^{2}+220-1}=0.825
$$

The effect size obtained shows that there is a large effect of the rural bank on the income of the farmers. As income increases, households' demand for goods, including food, increases as depicted by the Engel curves.

The effect size of credit on savings is calculated as 


$$
\text { EffectSize }=\frac{48.155^{2}}{48.155^{2}+220-1}=0.913
$$

A 0.913 indicates a large effect. In terms of labour force employed, the effect size is calculated as

$$
\text { EffectSize }=\frac{31.666^{2}}{31.666^{2}+220-1}=0.820
$$

Also showing a large effect, whiles for output shows the same story.

$$
\text { EffectSize }=\frac{44.351^{2}}{44.351^{2}+220-1}=0.899
$$

All in all, the Eta squared shows that the rural bank has had a significantly large effect on the lives of the farmers.

Other functions of the bank apart from granting of loans and savings accounts included paying of remittances, treasury bills and check clearing. Management of the Bank complained that, lack of data and information (records of operations of business), individual's or customers' data base is their major problems.

On question of whether the bank plays any role apart from managing accounts and loan disbursement. The management explained that they sometimes organize agricultural education for the clients who are farmers and are part of a formal organization.

They also play an advisory role on the use of the credit facility and sometimes as part of their social responsibility they reward the farmers with equipment. This was confirmed by some of the respondents who have once been at the receiving end of these benefits.

The bank according to management continues to provide support to institutions and projects in its catchment area, the beneficiaries of these social activities it engages in includes:

- Donations on National farmers Day;

- Scholarships.

The bank over the years has made a number of contributions in support of social/infrastructural development which has gone a long way to improve the standards of living of the rural folk in its catchment area.

A piece in The Ghana News Agency Business and Finance section of November 2005 alludes to the District Chief Executive (DCE), Mr Frank Kwame Busumtwi, commending the bank for offering bursaries to students of Akyem Achiase SSS and the provision of school desks for the Local Authority Primary School.

The banks contribution during events honouring farmers like the National Farmers Day was made reference to by the management. Item such as knapsack sprayers, cutlasses, wellington boots etc. are contribution the bank make during this annual event. This is to motivate farmers and to give them a lift in their work.

\section{Conclusion}

The study had the objective of assessing the impact of rural banks in promoting rural agricultural development to reduce poverty and increasing food security. A survey research was constructed using a structured questionnaire and where necessary an unstructured interview. A total of 220 farmers who are clients of South Birim Rural Bank Ltd in the Eastern Region of Ghana were interviewed.

The analysis shows that the impact of the rural banks was manifested in the area of employment generation, increase in incomes, savings and education. Seasonality's effect on agriculture in most developing countries cannot be neglected. This seasonality bring with it fluctuations in income which in the long run affect consumption leading to transitory food insecurity. For the rural farmer and the poor to survive there is therefore the need for households to have a certain credit that they can fall back on. Institutionalize finance like the rural banks, therefore stabilizes income and help to achieve food security.

The result shows farmers in the area enjoy the services of the bank and the bank itself has made significant impact on their lives not just only through the disbursement of credit or as something to fall back on when their income source is low but that it has had a high effect on output, income, savings and labour force. 
The high effect on output based on the Eta squared calculation give credence to the assertion that the rural bank stimulate agricultural production leading to availability of food- an important pillar of food security. The income calculation also meant that accessibility of the food can be insured.

The fulfilment of some social responsibility by the bank reflects it importance as a vehicle for rural development and not just a magnet for profit.

In conclusion for rural banks to make a significant impact in agricultural development and the bigger picture of improving the food security of the rural farmer, emphasis should be placed on more education for the farmers on the use of the credit.

\section{Acknowledgements}

The article was supported from grant Internal Grant Agency of the Faculty of Tropical AgriSciences no. 2015511307.

\section{References}

Addeah, K. (1989). The Law of Rural Banks in Ghana. Amattan Publication Limited.

Addeah, K. (2001). The legal and Regulatory Framework of Micro and Rural Finance Institutions. Ghana. Paper presented at the Rural Financial services project launch workshop, Agona-Swedru, Ghana.

Adjetey, S. M. A. (1978). The Financial System in Ghana, Research Memorandum, Research Department. Bank of Ghana, Accra

Ajai, N., \& Azeb, F. (2010). Rural Banking: The Case of Rural and Community Banks in Ghana.

Ardener, S. (1964). The Comparative Study of Rotating Credit Associations. The Journal of the Royal Anthropological Institute, 94(2), 22. http://dx.doi.org/10.2307/2844382

Aryeetey, E. (1994). A Study of Informal Finance in Ghana. London: Overseas Development Institute, Working Paper 78.

Aryeetey, E., \& Gockel, F. (1991). Mobilizing Domestic Resources for Capital Formation in Ghana: The Role of Informal Financial Markets, Research Paper 3. Nairobi: African Economic Research Consortium.

Asiama, J. P., \& Osei, V. (2007). Microfinance in Ghana: An Overview. Research Department Working Paper Bank of Ghana.

Association of Rural Banks. (1992). Annual Reports. (Unpublished report on file at the Association of Rural Banks). Accra, Ghana.

Bank of Ghana. (2004). Banking Act (Act 673) (pp. 2-8). Ghana Publishing Corporation, Accra.

Bank of Ghana. (2007). A note on microfinance in Ghana. Bank of Ghana Working Paper (WP/BoG-2007/01). Accra: Bank of Ghana.

Bauer, C. K. (1952). Proceedings of the International Conference on Cooperative Credit. Barkley, California.

Bortey, A. (1997). Credit and Savings Systems in Artisanal Fisheries in Ghana. Integrated Development of Artisanal Fisheries in West Africa (IDAF), Cotonou, Benin.

Bouman, F. J. A. (1989). Small, Short and Unsecured: Informal Finance in Rural India. Delhi: Oxford University Press.

Cohen, J. (1988). Statistical power analysis for the behavioral sciences (2nd ed.). Hillsdale, NJ: Lawrence Earlbaum Associates.

Desai, B. M. (1989). Objectives and role of Institutional Finance for Agricultural and Rural Development. Vikalpa, 14, 2.

Donald, G. (1976). Credit for Small Farmers in developing Countries. Boulder, CO: West View Press.

Egyir, I. S. (2010). Rural Women and Microfinance in Ghana: Challenges and Prospects. Contributed Paper presented at the Joint 3rd African Association of Agricultural Economists (AAAE) and 48th Agricultural Economists Association of South Africa (AEASA) Conference, Cape Town, South Africa, September 19-23. Retrieved September 18, 2013, from http://ageconsearch.umn.edu/bitstream/95782/1/34.\%20Rural\% 20women\%20and\%20microfinance\%20in\%20Ghana.pdf

Essel, T. T., \& Newsome, A. M. (2000). Effectiveness of Institutional Credit for Rural Development in Africa: A case Control Study of Rural Banks in Ghana. Journal of Sustainable Development in Africa, 2(1). 
FAO. (1994). Rural Poverty in the 1990s, in Rural Development Special Paper No. 15. Accra, Ghana: Ghana University Press.

Gyamfi, A. E. (1987). General principles and practices of Commercial Banks. Tema, Ghana Publication Corporation.

Habibullah, B. (1982). Financial Intermediation and Rural Economic Development. Bank Parikrama, 7, 3-4.

Hulme, D., \& Mosley, P. (1996). Finance against poverty: Volumes 1 and 2. London: Rout Ledge.

IFAD. (2008). The Republic of Ghana rural and agricultural finance program (RAFiP). Rome: International Fund for Agricultural Development.

Kimathi, M., Nandazi, M. M., Miller, C., \& Kipsang, D. N. K. (2008). Africa Agricultural Value Chain Financing, $3^{\text {rd }}$ African Rural and Agricultural Credit Association forum, Synthesis report.

Lele, U. (1989). Managing Agricultural Development in Africa: Three Articles on Lessons from Experience. The World Bank. Washington DC, (MADIA Discussion Paper No. 2).

Mann, C., Tinsey, J., Tedjo, G., \& Nwadei, T. (2010). Ghana's Rural Finance System and Climate Regime. Retrieved September 16, 2013, from http://www.bu.edu/gdp/files/2011/01/Capstone-2010-A-Ghanas-rural -finance-system-and-climate-regime.pdf

Mellor, J. W. (1976). The New Economics of Growth: Strategy for India and the Developing World (Chapter 17). Ithaca, New York: Cornell University Press

Mensah, W. A. (1993). Study of the Rural Finance Sector in Ghana. Unpublished paper.

Nissanke, M., \& Aryeetey, E. (1998). Financial Integration and Development. London: Routledge Studies in Development Economics.

Oloyede, J. A. (2008). Informal financial sector, savings mobilization and rural development in Nigeria: Further evidence from Ekiti state of Nigeria. African Economic and Business Review, 6(1), 35-63.

Owusu-Acheampong, K. (1986). Rural credit in Ghana. Accra: Criot Press. Quarterly Newsletter of Bank of Ghana, 6, 3 .

Pande, R., \& Burgess, R. (2005). Can Rural Banks Reduce Poverty? Evidence from the Indian Social Banking Experiment. American Economic Review, 95(3), 780-795. http://dx.doi.org/10.1257/0002828054201242

Porter, R. C. (1964). The Promotion of Banking Habits and Economic Development. Journal of Development Studies, 2, 346-366. http://dx.doi.org/10.1080/00220386608421196

Ranade, C. G. (1994). Rural Finance in Ghana. Accra. Unpublished paper.

Seini, W. A. (2002). Agricultural Growth and Competitiveness Under Policy Reforms in Ghana. ISSER Technical Publication Series, No. 61, Legon, Accra. The Institute of Statistical, Social and Economic Research (ISSER).

South Birim Rural Bank posts 930.1 million cedis profit. (2005, November 27). GNA. Retrieved September 9, 2013, from http://www.modernghana.com/news/90937/1/south-birim-rural-bank-posts-9301-millioncedis-pr.html

Von Pischke, J. D., Adams, D. W., \& Donald, G. (Eds.). (1983). Rural Financial Markets in Developing Countries: Their Use and Abuse. Baltimore: The John Hopkins University Press.

World Bank Report. (1975). Rural Development. Washington DC: World Bank.

World Bank. (2007). Finance for All? Policies and Pitfalls in Expanding Access. Washington DC: World Bank.

\section{Notes}

Note 1. Examples of Cottage Industries are bricks and tiles, construction, furniture making, tailoring etc.

Note 2. Susu collection is a system in which a person (e.g. a trader, an artisan, etc) decides to make a daily contribution to another person, the Susu collector (the Bank), for an agreed period, usually a month (31 days). In this case, officer from the bank calls on the registered customer at the workplace daily, or at agreed intervals, for the customer to make a lodgment into his/her account. 


\section{Copyrights}

Copyright for this article is retained by the author(s), with first publication rights granted to the journal.

This is an open-access article distributed under the terms and conditions of the Creative Commons Attribution license (http://creativecommons.org/licenses/by/3.0/). 